\title{
Is medical management of paediatric heart failure evidence based?
}

\author{
Anke Furck, Zdeněk Slavík \\ Royal Brompton Hospital, Royal Brompton \& Harefield NHS Foundation Trust, London, United Kingdom
}

Furck A, Slavík Z. Is medical management of paediatric heart failure evidence based? Cor Vasa 2011;53:273-277.

Treatment of paediatric heart failure is based on much less evidence when compared with corresponding treatment in adult population. Nevertheless, successful treatment methods have been adjusted or developed for paediatric patients with chronic and acute heart failure and promising future trends exist.

Key words: Heart failure - Paediatrics - Evidence base

Furck A, Slavík Z. Je konzervativní léčba srdečního selhání u dětí založena na vědeckých důkazech? Cor Vasa 2011;53:273-277.

Léčba srdečního selhání je u dětí založena na omezených důkazech ve srovnání s odpovídají léčbou u dospělých. Přesto existují úspěšné léčebné metody přizpůsobené nebo nově vyvinuté pro dětské pacienty s chronickým nebo akutním srdečním selháním a existují i slibné nové léčebné trendy.

Klíčová slova: Srdeční selhání - Pediatrie - Důkazy

Address: MUDr. Zdeněk Slavík, MD (UK), FRCPCH, Royal Brompton Hospital, Royal Brompton \& Harefield NHS Foundation Trust, Sydney Street, London SW3 6NP, United Kingdom, e-mail: Zdenek.Slavik@rbht.nhs.uk

There has been ever increasing emphasis on the use of evidence based practice in all areas of medical, surgical, and nursing care over the last decade or so. This even lead to creation of a government sponsored body reviewing the evidence for good practice and issuing recommendations in the United Kingdom. ${ }^{1,2}$ Moreover, large prospective trials have formed the basis of evidence based treatment in adult cardiac patients for some time now. ${ }^{3-5}$ We sought to review similar evidence for prevention and/or treatment of chronic and acute heart failure in paediatric population.

\section{Causes of paediatric heart failure}

Congenital heart defects (CHD) are the most common cause of heart failure in paediatric population worldwide. They are also the most common congenital anomalies. They added $10 \%$ to infant mortality and $50 \%$ to mortality from all congenital defects in the United Kingdom in 1990's. ${ }^{6}$ Progress in the management of CHD led to reduction in 1-year mortality in almost 5500 children treated surgically or by catheter interventions from $8.5 \%$ in $2000-2001$ to $2.7 \%$ in 2006-2007. ${ }^{7.8}$ This successful reduction in mortality did not take away the burden of a significant morbidity associated with treatment and prevention of congestive heart failure in children with congenital heart defects.
Additional causes of heart failure include myocarditis, cardiomyopathy, dysrhythmias, drug toxicity, and sepsis or metabolic disease. ${ }^{9-13}$ Therefore both acute and chronic heart failure in children still presents difficult therapeutic problem in the current era.

\section{Prevention and treatment}

\section{Chronic heart failure}

Diuretics are the most frequently used medication in the treatment of heart failure in children despite very little published evidence about their clinical effect or pharmacokinetics in this age group. ${ }^{14,15}$ Given their widespread use and anecdotal beneficial clinical effect, paediatric prospective, placebo-controlled study is currently inconceivable.

Limited published evidence exists on the use of vasodilators in mitral and/or aortic regurgitation in paediatric population (Table 1). ${ }^{16-19}$ Strikingly low numbers of patients were included in the so far published series not to mention the presence of a control group in only one of these. ${ }^{17}$ The only so far published prospective controlled trial on the use of enalapril in heterogeneous group of young patients with single ventricle circulation failed to show any improvement in clinical, biochemical or echocardiographic parameters. ${ }^{20}$ 
Table 1 Published evidence on the use of vasodilators in paediatric heart failure

\begin{tabular}{lccllll}
\hline Author & Year & No & $\begin{array}{l}\text { Age } \\
\text { (years) }\end{array}$ & Lesion & Drug & Effect \\
\hline Hsu $^{20}$ & 2010 & 185 & $<1.2$ & Single ventricle & Enalapril & None \\
\hline Gisler $^{16}$ & 2008 & 18 & $5.4-10$ & AR & $\begin{array}{l}\text { Captopril } \\
\text { Enalapril }\end{array}$ & None \\
\hline Mori $^{17}$ & 2000 & 24 & $0.3-16$ & AR or MR & Enalapril & Reduced LV size and LV mass \\
\hline Calabro $^{18}$ & 1999 & 10 & $3-16$ & MR & Enalapril & Reduced LV size and wall stress \\
\hline Alehan $^{19}$ & 1998 & 20 & $12-16$ & AR & Captopril & Reduced LV size and wall stress \\
\hline AR
\end{tabular}

$\mathrm{AR}$ - aortic valve regurgitation, $\mathrm{LV}$ - left ventricle, $\mathrm{MR}$ - mitral valve regurgitation

Beneficial role of beta-receptor blocking medication in children with chronic myocardial dysfunction is somewhat better documented including its pharmacokinetics when compared with the above treatment modalities (Table 2). ${ }^{21-31}$ However, the most promising prospective, multicentric, placebo-controlled trial to date did not show any tangible benefit in administration of carvedilol to 62 children with dilated cardiomyopathy. ${ }^{29}$ Some benefit was observed in the subgroup of 17 patients with congenital heart defects and left ventricular failure.

Further disappointing results came from a retrospective review of the use of combined therapy with angiotensin-converting enzyme inhibitors and beta-receptor blockers in 57 children with dilated cardiomyopathy between 1976 and $2005 .{ }^{31}$ No added benefit was found in 5-year transplant-free survival when compared with digoxin treatment only (59\% versus $68 \%$ in digoxin only treated patients, $p=$ NS).

\section{Acute heart failure}

Incidence of low cardiac output state has been stable at around $25 \%$ early after surgical treatment of CHD for more than 30 years now. ${ }^{32-34}$ PRIMACORP study still remains a unique paediatric prospective, placebo-controlled study showing beneficial effect of inodilator Milrinone on low cardiac output state postoperatively. ${ }^{34}$ With 238 patients included in the study, peroperative and postoperative administration of Milrinone reduced the incidence of low cardiac output state by $55 \%(p=0.023)$. No difference in postoperative mortality between the control and treatment group was encountered. Nevertheless, treatment with Milrinone decreased the length of postoperative artificial ventilation from 3.1 to 1.4 days $(p=0.001)$ and length of hospital stay from 11.3 to 8.9 days $(p=0.016)$. These conclusions are supported by previous smaller haemodynamic study showing increased cardiac index and reduced systemic and pulmonary vascular resistance by Milrinone bolus and continuous infusion treatment in neonates following cardiac operation..$^{35}$ Moreover, Milrinone was shown to have positive direct myocardial effect in infants with low cardiac output state when added to catecholamine treatment early postoperatively. ${ }^{36}$

Promising results have recently been published on the use of vasopressin in paediatric patients suffering from profound vasodilatation associated with sepsis or cardiopulmonary bypass. ${ }^{37}$ Vasopressin administered as a bolus or continuous infusion led to significant increase in systemic blood pressure allowing for reduction of catecholamine doses. Similar preliminary favourable results were reported on vasopressin use in paediatric cardiac arrest refractory to cardiopulmonary resuscitation and adrenalin administration. ${ }^{38}$

The use of mechanical circulatory support is the best documented treatment in paediatric heart failure to date. ${ }^{39-42}$ Davies et al reviewed 2535 patients younger than 19 years

Table 2 Published evidence on the use of beta-receptor blocking medication in paediatric heart failure

\begin{tabular}{lccllll}
\hline Author & Year & No & Age (years) & Lesion & Drug & Effect \\
\hline Bruns $^{23}$ & 2001 & 46 & $0.3-19$ & DCM/CHD & Carvedilol & Improved LVSF and NYHA class \\
\hline Azeka $^{24}$ & 2002 & 14 & $<15$ & DCM & Carvedilol & Improved LVEF \\
\hline Williams $^{25}$ & 2002 & 12 & $<15$ & DCM/CHD & Metoprolol or carvedilol & Improved LVEF \\
\hline Buckhorn $^{26}$ & 2003 & 8 & $<1$ & CHD & Propranolol & Improved diastolic function \\
\hline Rusconi $^{27}$ & 2004 & 24 & $0.8-13$ & DCM & Carvedilol & Improved LVEF and NYHA class \\
\hline Blume $^{28}$ & 2006 & 20 & $0.8-17$ & DCM/CHD & Carvedilol & Improved LVEF \\
\hline Shaddy $^{29}$ & 2007 & 103 & $<18$ & DCM/CHD & Carvedilol & No difference in outcome, improved LV contractility in CHD \\
\hline Bajcetic $^{30}$ & 2008 & 21 & $0.5-16$ & DCM & Carvedilol & Improved LV ejection fraction and NYHA class \\
\hline Kantor $^{31}$ & 2010 & 57 & $<15$ & DCM & $\begin{array}{l}\text { Propranolol, metoprolol, } \\
\text { Carvedilol }\end{array}$ & No effect on transplant-free survival \\
\hline
\end{tabular}

CHD - congenital heart disease, DCM - dilated cardiomyopathy, LV - left ventricle, LVEF - left ventricular ejection fraction, LVSF - left ventricular shortening fraction 
undergoing heart transplantation between 1995-2005. ${ }^{39}$ Mechanical support was used successfully as a bridge to transplantation in 431 patients (17\%) without any difference in long term survival. Moreover, recent evidence from 255 patients below 18 years of age with acute myocarditis supported by extracorporeal membrane oxygenation (ECMO) showed survival to hospital discharge in $61 \%$ of the patients. ${ }^{40}$

Heart transplantation has been well established treatment of end-stage paediatric heart failure with satisfactory results over the last couple of decades. ${ }^{43,44}$ Nevertheless, both acute and chronic rejection have significant adverse impact on the medium and long-term survival in paediatric heart transplant recipients in the current era. ${ }^{45,46}$

Intriguing results calling to question indications for heart transplantation in children with acute heart failure were published by O'Sullivan et al. ${ }^{47}$ They treated 27 young patients (age 0.1-72 months) with acute severe heart failure between 1988-2005. Three patients required ECMO support in the course of their treatment. Complete recovery without heart transplantation was observed in $66 \%$ and $96 \%$ of the patients at 18 and 24 months, respectively. This experience is supported by Amabile et al who studied retrospectively 11 patients with acute myocarditis presenting between 1998 and 2003.8 All patients received inotropic support and corticosteroids with seven patients treated by intravenous immunoglobulin as well. Long-term survival with normal left ventricular ejection fraction was observed in 10 children (90\%) despite cardiopulmonary resuscitation required in five of these.

\section{Future trends in paediatric heart failure treatment}

There is emerging evidence that paediatric heart transplantation candidates with pulmonary vascular resistance previously considered too high for successful orthotopic heart transplantation may benefit from treatment with various pulmonary vasodilators. ${ }^{49}$ Combined therapy including sildenafil, bosentan, inhaled nitric oxide, and iloprost has been used in 7 patients with pre-transplantation calculated total pulmonary vascular resistance between 6-20 Wood's units. Successful heart transplantation was carried out following pre-treatment with bosentan or sildenafil and inhaled nitric oxide was used in all patients in the early postoperative period. Inhaled iloprost was required in one patient long-term. All patients survived one year after heart transplantation.

The use of novel calcium sensitizer and peripheral vasodilator Levosimendan has shown promising preliminary results in the treatment of myocardial failure in patients with cardiomyopathy or congenital heart disease in total of 41 paediatric patients published so far and in our institutional experience with further 11 patients. ${ }^{50-53}$

Synthetic brain natriuretic peptide (Neseritide) combines systemic venous and arterial vasodilating effect with myocardial lusitropic effect. Its administration to 17 neonates and 30 infants in postoperative low cardiac output state as an adjunct to conventional treatment had neutral directly monitored haemodynamic effect but led to improved urine output. ${ }^{54}$

Concept of remote ischaemic pre- and per-conditioning is based on temporary ischaemia of one organ having protective effect against subsequent or concomitant ischaemia and reperfusion injury of other organs. ${ }^{55}$ It is likely to be at least partly related to generalised suppression of transcription of pro-inflammatory genes in leukocytes and to upregulating cardioprotective genes in myocytes by primary organ ischaemia.$^{56}$ In paediatric clinical study, repeat mild lower limb ischaemia by blood pressure cuff inflation (4-times for $5 \mathrm{~min}$ ) before cardiac surgery in children led to lower troponin levels and inotrope score when compared with a control group postoperatively. ${ }^{57}$ Similar protocol involving 30 infants undergoing cardiac surgery led to upregulation of genes involved in protection against oxidative stress and suppression of pro-inflammatory genes. ${ }^{58}$

Ischaemic and reperfusion injury has been extensively studied both in myocardial infarction and after cardiac arrest. ${ }^{59,60}$ It is widely accepted that cellular and mitochondrial calcium overload is an important mechanism of injury and apoptosis. ${ }^{61}$ Cyclosporin A appears a promising medication limiting cellular injury in experimental setting. ${ }^{62}$ It has stabilising effect on mitochondrial permeability transition pores in oxidative stress and protects against mitochondrial calcium overload at the time of reperfusion injury. Cyclosporin A has protective effect on central nervous system in paediatric heart transplant recipients following cardiac arrest. ${ }^{63}$ Moreover, experimental studies showed its protective effect on central nervous system within 24 hours of ischaemic and reperfusion injury. ${ }^{64}$ There are first reports on similar protective effect of cyclosporin $\mathrm{A}$ in transient myocardial ischaemia in experimental and adult clinical studies. ${ }^{65,66}$

There is also emerging evidence that stem cell transplantation may have its role even in the treatment of paediatric end-stage heart failure. ${ }^{67}$

\section{Conclusions}

Like with many other paediatric treatment protocols, evidence for medical management of paediatric heart failure is inevitably limited in comparison with corresponding adult interventions. Cause of this limitation is multifactorial and spans from ethical issues related to trials conducted in neonates, infants or children to restricted availability of resources given much smaller market for and revenues from any new and successful treatment modality. Nevertheless, marked improvement in the results of congenital and acquired paediatric heart disease treatment has been achieved over the past decade. There also exist promising new avenues to explore be it on much smaller scale than in adult population in future.

\section{References}

1. NICE: Chronic heart failure: management of chronic heart failure in adults in primary and secondary care. www.guidance.nice.org.uk/CG108 
2. NICE: Balloon angioplasty with or without stenting for coarctation or recoarctation of aorta in adults and children. www.guidance.nice.org.uk/ IPG74

3. Packer M, Fowler MB, Roecker EB, et al. Effect of carvedilol on the morbidity of patients with severe chronic heart failure: result of the carvedilol prospective randomized cumulative survival (COPERNICUS) study. Circulation 2002;106:2194-2199.

4. Poole-Wilson PA, Swedberg K, Cleland JG, et al. Comparison of carvedilol and metoprolol on clinical outcomes in patients with chronic heart failure in the Carvedilol or Metoprolol European Trial (COMET) randomised controlled trial. Lancet 2003;362:7-13.

5. De Luca L, Colucci WS, Nieminen MS, et al. Evidence-based use of levosimendan in different clinical settings. Eur Heart J 2006;27:1908-1920.

6. Richmond S, Wren C. Early diagnosis of congenital heart disease. Semin Neonatol 2001;6:27-35.

7. Gibbs JL, Monro JL, Cunningham D, Rickards A. Survival after surgery or therapeutic catheterisation for congenital heart disease in children in the United Kingdom: analysis of the central cardiac audit database for 2000-1. BMJ 2004;328:611.

8. www.CCAD.org.uk/paedanalysis

9. Andrews RE, Fenton MJ, Ridout DA, Burch M. New-onset heart failure due to heart muscle disease in childhood: a prospective study in the United Kingdom and Ireland. Circulation 2008;117:79-84.

10. Lipshultz SE, Sleeper LA, Towbin JA, et al. The incidence of pediatric cardiomyopathy in two regions of the United States. N Engl J Med 2003; 348:1647-1655.

11. Wilkinson JD, Landy DC, Colan SD, et al. The pediatric cardiomyopathy registry and heart failure: key results from the first 15 years. Heart Fail Clin 2010;6:401-413.

12. Lipshultz SE, Alvarez JA, Scully RE. Anthracycline associated cardiotoxicity in survivors of childhood cancer. Heart 2008;94:525-533.

13. Connuck DM, Sleeper LA, Colan SD, et al. Characteristics and outcomes of cardiomyopathy in children with Duchenne or Becker muscular dystrophy: A comparative study from The Pediatric Cardiomyopathy Registry. Am Heart J 2008;155:998-1005.

14. van der Vorst MM, Ruis-Dudok van Heel I, Kist-van Holte JE, et al. Continuous intravenous furosemide in haemodynamically unstable children after cardiac surgery. Int Care Med 2001;27:711-715.

15. van der Vorst MM, Kist JE, van der Heiiden AJ, Burggraf J. Diuretics in pediatrics: current knowledge and future prospects. Paediatr Drugs 2006; 8:245-264.

16. Gisler F, Knirsch W, Harpes P, Bauersfeld U. Effectiveness of angiotensin-converting enzyme inhibitors in pediatric patients with mid to severe aortic valve regurgitation. Pediatr Cardiol 2008;29:906-909.

17. Mori $Y$, Nakazawa M, Tomimatsu H, Momma K. Long-term effect of angiotensin-converting enzyme inhibitor in volume overloaded heart during growth: a controlled pilot study. Am Coll Cardiol 2000;36:270-275.

18. Calabro R, Pisacane C, Pacileo G, Russo MG. Hemodynamic effect of a single oral dose of enalapril among children with asymptomatic chronic mitral regurgitation. Am Heart J 1999;138:955-961

19. Alehan D, Ozkutlu S. Beneficial effect of 1-year captopril therapy in children with chronic aortic regurgitation who have no symptoms. Am Heart J 1998;135:598-603.

20. Hsu DT, Zak V, Mahony $L$, et al. Enalapril in infants with single ventricle: results of a multicenter randomized trial. Circulation 2010;122:333-340.

21. Silva JN, Canter CE. Current management of pediatric dilated cardiomyopathy. Curr Opin Cardiol 2010;25:80-87.

22. Albers S, Meibohm B, Mir TS, Laer S. Population pharmacokinetics and dose simulation of carvedilol in paediatric patients with heart failure. $\mathrm{Br} J$ Clin Pharmacol 2007;65:511-522.

23. Bruns LA, Chrisant MK, Lamour JM, et al. Carvedilol as therapy in pediatric heart failure: an initial multicenter experience. J Pediatr 2001;138:505-511.

24. Azeka E, Franchini Ramirez JA, Valler C, Alcides Bocchi E. Delisting of infants and children from the heart transplantation waiting list after carvedilol treatment. J Am Coll Cardiol 2002;40:2034-2038.

25. Williams RV, Tani LY, Shaddy RE. Intermediate effects of treatment with metoprolol or carvedilol in children with left ventricular systolic dysfunction. J Heart Lung Transplant 2002;21:906-909.

26. Buckhorn R, Hulpke-Wette M, Ruschewski W, et al. Effects of therapeutic beta blockade on myocardial function and cardiac remodelling in congenital cardiac disease. Cardiol Young 2003;13:36-43.
27. Rusconi P, Gomez-Arin O, Rossique-Gonzales M, et al. Carvedilol in children with cardiomyopathy: 3-year experience at a single institution. J Heart Lung Transplant 2004;23:832-838.

28. Blume ED, Canter CE, Spicer R, et al. Prospective, single-arm protocol of carvedilol in children with ventricular dysfunction. Pediatr Cardiol 2006; 27:336-342.

29. Shaddy RE, Boucek MM, Hsu DT, et al. Carvedilol for children and adolescents with heart failure. JAMA 2007;298:1171-1179.

30. Bajcetic M, Kokic Nikolic A, Djukic M, et al. Effects of carvedilol on left ventricular function and oxidative stress in infants and children with idiopathic dilated cardiomyopathy: a 12-month, two-center, open-label study. Clin Ther 2008;30:702-714.

31. Kantor PF, Abraham JR, Dipchand Al, et al. The impact of changing medical therapy on transplantation-free survival in pediatric dilated cardiomyopathy. J Am Coll Cardiol 2010;55:1377-1384.

32. Parr GV, Blackstone EH, Kirklin JW. Cardiac performance and mortality early after intracardiac surgery in infants and young children. Circulation 1975;51:867-874.

33. Wernovsky G, Wypij D, Jonas RA, et al. Postoperative course and hemodynamic profile after the arterial switch operation in neonates and infants. A comparison of low-flow cardiopulmonary bypass and circulatory arrest. Circulation 1995;92:2226-2235.

34. Hoffman TM, Wernovsky G, Atz AM, et al. Efficacy and safety of milrinone in preventing low cardiac output syndrome in infants and children after corrective surgery for congenital heart disease. Circulation 2003; 107:996-1002.

35. Chang AC, Atz AM, Wernovsky G, et al. Milrinone: systemic and pulmonary hemodynamic effects in neonates after cardiac surgery. Crit Care Med 1995;23:1907-1914.

36. Duggal B, Pratap U, Slavik Z, et al. Milrinone and low cardiac output following cardiac surgery in infants: Is there a direct myocardial effect? Pediatr Cardiol 2005;26:1-5.

37. Singh VK, Sharma R, Agrawal A, Varma A. Vasopressin in the pediatric cardiac intensive care unit: Myth or reality. Ann Pediatr Card 2009;2:65-73.

38. Matok I, Vardi A, Augarten A, et al. Beneficial effects of terlipressin in prolonged pediatric cardiopulmonary resuscitation: A case series. Crit Care Med 2007;35:1161-1164.

39. Davies RR, Russo MJ, Hong KN, et al. The use of mechanical circulatory support as a bridge to transplantation on pediatric patients: an analysis of the United Network for Organ Sharing Database. J Thorac Cardiovasc Surg 2008;135:421-427.

40. Rajagopal SK, Almond CS, Laussen PC, et al. Extracorporeal membrane oxygenation for the support of infants, children, and young adults with acute myocarditis: a review of the Extracorporeal Life Support Organization Registry. Crit Care Med 2010;38:382-387.

41. Zimmerman $H$, Covington $D$, Smith $R$, et al. Recovery of dilated cardiomyopathies in infants and children using left ventricular assist device. ASAIO J 2010;56:364-368.

42. Nahum E, Dagan O, Lev A, et al. Favorable outcome of pediatric fulminant myocarditis supported by extracorporeal membranous oxygenation. Pediatr Cardiol 2010;31:1059-1063.

43. Groetzner J, Reichart B, Roemer U, et al. Cardiac transplantation in pediatric patients: fifteen-year experience of a single center. Ann Thorac Surg 2005; 79:53-60.

44. Phelps CM, Tissot $C$, Buckvold $\mathrm{S}$, et al. Outcome of acute graft rejection associated with hemodynamic compromise in pediatric heart transplant recipients. Pediatr Cardiol 2011;32:1-7.

45. Webber SA, Naftel DC, Parker J, et al. Late rejection episodes more than 1 year after pediatric heart transplantation: risk factors and outcomes. J Heart Lung Transplant 2003;22:869-875.

46. Zuppan CW, Wells LM, Kerstetter JC, et al. Cause of death in pediatric and infant heart transplant recipients: review of a 20 -year, single-institution cohort. J Heart Lung Transplant 2009;28:579-584.

47. O'Sullivan JJ, Roche SL, Crossland DS, et al. Recovery of heart function in children with acute severe heart failure. Transplantation 2008;85:975-979.

48. Amabile N, Fraisse A, Bouvenot J, et al. Outcome of acute fulminant myocarditis in children. Heart 2006;92:1269-1273.

49. Daftari B, Alejos JC, Perens G. Initial experience with sildenafil, bosentan, and nitric oxide for pediatric cardiomyopathy patients with elevated pulmonary vascular resistance before and after orthotopic heart transplantation. J Transplant 2010;2010:656984. 
50. Namachivayam P, Crossland DS, Butt WW, Shekedermian LS. Early experience with levosimendan in children with ventricular dysfunction. Pediatr Crit Care Med 2006;7:445-448.

51. Lechner $E$, Moosbauer W, Pinter M, et al. Use of levosimendan a new inodilator, for postoperative myocardial stunning in premature neonate. Pediatr Crit Care Med 2007;8:61-63.

52. Di Chiara L, Ricci Z, Garisto C, et al. Initial experience with levosimendan infusion for preoperative management of hypoplastic left heart syndrome. Pediatr Cardiol 2010;31:166-167.

53. Egan JR, Clarke AJ, Williams $S$, et al. Levosimendan for low cardiac output: a pediatric experience. J Intensive Care Med 2006;21:183-187.

54. Simsic JM, Mahle WT, Cuadrado A, et al. Hemodynamic effects and safety of nesiritide in neonates with heart failure. J Intensive Care Med 2008;23:389-395.

55. Kharbanda RK, Nielsen TT, Redington AN. Translation of remote ischaemic preconditioning into clinical practice. Lancet 2009;374:1557-1565.

56. Konstantinov IE, Arab S, Li J, et al. The remote ischemic preconditioning stimulus modifies gene expression in mouse myocardium. J Thorac Cardiovasc Surg 2005;130:1326-1332.

57. Cheung MM, Kharbanda RK, Konstantinov IE, et al. Randomized controlled trial of the effects of remote ischemic preconditioning on children undergoing cardiac surgery: first clinical application in humans. J Am Coll Cardiol 2006;47:2277-2282.

58. Zhou W, Zeng $D$, Chen $R$, et al. Limb ischemic preconditioning reduces heart and lung injury after an open heart operation in infants. Pediatr Cardiol 2010;31:22-29.
59. Quintana M, Kahan T, Hjemdahl P, et al. Pharmacological prevention of reperfusion injury in acute myocardial infarction. A potential role for adenosine as a therapeutic agent. Am J Cardiovasc Drugs 2004;4:159-167.

60. Warner DS. Pharmacologic protection from ischemic neuronal injury. J Neurosurg Anesthesiol 2004;16:95-97.

61. Peng Tl, Jou MJ. Oxidative stress caused by mitochondrial calcium overload. Ann N Y Acad Sci 2010;1201:183-188.

62. Matsubara M, Ranji M, Leshnower BG, et al. In vivo fluorometric assessment of cyclosporine on mitochondrial function during myocardial ischemia and reperfusion. Ann Thorac Surg 2010;89:1532-1537.

63. Pratap U, Slavik Z, Ofoe V, et al. Pediatric cardiopulmonary resuscitation and cyclosporin A - is there a clinical benefit? Čes-Slov Pediatr 2004;59:605-609.

64. Sullivan PG, Thompson M, Scheff SW. Continuous infusion of cyclosporin A postinjury significantly ameliorates cortical damage following traumatic brain injury. Exp Neurol 2000;161:631-637.

65. Nathan M, Friehs I, Choi YH, et al. Cyclosporin A but not FK-506 protects against dopamine-induced apoptosis in the stunned heart. Ann Thorac Surg 2005;79:1620-1626.

66. Ivanes F, Mewton N, Rioufol G, et al. Cardioprotection in the clinical setting. Cardiovasc Drugs Ther 2010;24:281-287.

67. Olgunturk R, Kula S, Sucak GT, et al. Peripheric stem cell transplantation in children with dilated cardiomyopathy: preliminary report of first two cases. Pediatr Transplant 2010;14:257-260.

Received 3. 1. 2011 